\title{
Persepsi dan sikap masyarakat terhadap perlindungan dan pengelolaan mangrove di Kecamatan Sungai Apit Kabupaten Siak
}

\author{
Siti Fatonah ${ }^{1 *}$, Rasoel Hamidy ${ }^{2}$, Aras Mulyadi ${ }^{3}$, Efriyeldi $^{4}$ \\ ${ }^{1}$ Jurusan Biologi Fakultas Matematika dan Ilmu Pengetahuan Alam Universitas Riau \\ ${ }^{2}$ Program Doktor Ilmu Lingkungan Program Pascasarjana Universitas Riau \\ ${ }^{3,4}$ Program Doktor Ilmu Lingkungan Pascasarjana dan Jurusan Ilmu Kelautan, Fakultas Perikanan dan \\ Kelautan, Universitas Riau \\ *Koresponden E-mail: fath0104@gmail.com
}

(Diterima: 17 November 2021|Disetujui: 12 Januari 2022 |Diterbitkan: 31 Januari 2022)

\begin{abstract}
Mangrove forest in Sungai Apit Sub District, Siak District, Riau is one of the mangrove ecosystems in Riau Province which has experienced a reduction in land area and is the widest in Siak Regency. This study aims to determine the perceptions and attitudes of the community in the protection and management of mangroves. The research was conducted in three villages in Sungai Apit Sub District, namely Rawa Mekar Jaya, Sungai Rawa and Mengkapan. Data was collected through observation and interviews with the community using mangroves. The results showed that the perception of the community in Sungai Apit towards the function and management of mangroves is classified as very good, while the attitude of the community towards the protection and management of mangroves is classified as good. The perception and attitude of the people of Rawa Mekar Jaya and Meng Kapan are better than the people of Sungai Rawa. Community involvement in rehabilitation activities is generally only at the time of the project and due to wages. The community has a high awareness of utilizing mangrove resources in a sustainable manner. The community has a high awareness of the protection and management of mangroves, but their involvement in rehabilitation activities requires money to compensate for the time and energy used. Therefore, alternative activities are needed that can increase funding sources and increase funding sources in local institutions related to mangroves.
\end{abstract}

Keywords: local community; mangrove function; mangrove management; Sungai Apit Siak

\section{PENDAHULUAN}

Ekosistem mangrove menyediakan sumber daya dan jasa bagi sumber penghidupan masyarakat pesisir. Sumber daya mangrove ini telah digunakan oleh masyarakat lokal secara komersial selama beberapa dekade dan berkontribusi terhadap keberlanjutan dan ketahanan ekonomi masyarakat lokal (Damastuti \& de Groot, 2017). Berbagai sumberdaya mangrove merupakan sumber penghidupan masyarakat lokal, meliputi kayu bakar, kayu bahan bangunan, ikan, kerang, kepiting bakau, dan (Muntalif et al., 2013; Motoku et al., 2014; Widiastuti et al., 2016; Sondak et al., 2019)

Manfaat ekosistem mangrove untuk sumber penghidupan masyarakat menjadi berkurang karena ekosistem mangrove mengalami tekanan yang meningkat (Prawita, 2018; Sarhan \& Tawfik, 2018; Owuor et al., 2019). Kerusakan hutan mangrove di Indonesia antara lain disebabkan karena alih fungsi lahan menjadi tambak, perkebunan kelapa sawit, eksploitasi berlebih pohon mangrove, aktivitas industri, dan perluasan pemukiman (Juwita et al., 2015; Winarno et al., 2016). Oleh karena itu perlu upaya untuk mengurangi tingkat kerusakan hutan mangrove dan upaya rehabilitasi hutan mangrove. Keterlibatan masyarakat dalam pengelolaan mangrove atau dikenal sebagai pengelolaan mangrove berbasis masyarakat penting dalam meminimalkan gangguan manusia dan mencapai penggunaan sumber daya mangrove secara berkelanjutan. Pengelolaan berbasis masyarakat menekankan partisipasi masyarakat dalam identifikasi sumber daya, menetapkan prioritas pembangunan, dan pemilihan serta adaptasi teknologi untuk praktik pengelolaan berkelanjutan (Damastuti \& de Groot, 2017). Pengelolaan hutan yang melibatkan masyarakat lokal lebih berhasil dibandingkan pengelolaan oleh lembaga negara tanpa partisipasi masyarakat yang dibuktikan dengan tingkat deforestasi dan degradasi hutan yang lebih rendah pada hutan kemasyarakatan (Kongkeaw et al., 2019).

Keberhasilan upaya konservasi suatu kawasan ekosistem misalnya ekosistem mangrove sangat dipengaruhi oleh partisipasi masyarakat lokal. Konservasi sumber daya alam yang efektif hanya mungkin terjadi dengan adanya pemahaman tentang sikap dan persepsi yang baik dari masyarakat lokal Meskipun konservasi sumber daya lahan basah misalnya lahan mangrove dipengaruhi oleh keputusan kebijakan yang lebih besar, namun pemanfaatannya 
yang berkelanjutan bergantung terutama pada masyarakat yang tinggal di dekat lahan mangrove (Badola et al., 2012). Keberhasilan pengelolaan berbasis masyarakat tergantung pada pemahaman persepsi masyarakat lokal yang berhubungan sumber daya ekosistem (Owuor et al., 2019). Persepsi masyarakat tentang fungsi mangrove dan partisipasi masyarakat lokal dalam pengelolaan mangrove penting dalam perlindungan dan pengelolaan mangrove (Damastuti \& de Groot, 2017).

Ekosistem mangrove di Kecamatan Sungai Apit Kabupaten Siak, Propinsi Riau merupakan salah satu ekosistem mangrove yang telah mengalami penurunan luas lahan. Luas mangrove pada tahun 1990 sampai 1996 sekitar 866,7 ha, mulai tahun 2000 terjadi penurunan luas mangrove menjadi 578,8 ha, kemudian terjadi penurunan menjadi 312,1 ha pada tahun 2015 (KLHK, 2019). Upaya pengelolaan mangrove telah dilakukan oleh masyarakat di kawasan mangrove Sungai Apit, antara lain rehabilitasi mangrove, penerapan peraturan terkait pengelolaan mangrove, serta penyediaan berbagai fasilitas untuk ekowisata mangrove. Pengelolaan mangrove yang melibatkan masyarakat lokal di Sungai Apit penting dalam pemanfaatan sumber daya mangrove berkelanjutan, perlindungan dan pengelolaan mangrove. Beberapa hal penting dalam pengelolaan mangrove yang melibatkan masyarakat meliputi persepsi masyarakat terhadap keberadaan hutan mangrove dan sikap masyarakat terhadap perlindungan dan pengelolaan mangrove. Studi tentang persepsi dan sikap masyarakat dalam perlindungan dan pengelolaan mangrove penting dalam memprediksi sikap masyarakat lokal yang akan mempengaruhi kebijakan dalam perlindungan dan pengelolaan. Dengan memperhatikan permasalahan yang berhubungan dengan sikap masyarakat maka perencanaan perlindungan dan pengelolaan mangrove yang akan datang akan berjalan lebih efektif. Penelitian ini bertujuan untuk mengetahui persepsi, sikap dan perilaku masyarakat dalam perlindungan dan pengelolaan mangrove di kawasan mangrove Kecamatan Sungai Apit Kabupaten Siak.

\section{BAHAN DAN METODE}

Penelitian dilaksanakan di Kecamatan Sungai Apit Kabupaten Siak, di tiga kampung, yaitu Kampung Rawa Mekar Jaya, Sungai Rawa, dan Mengkapan (Gambar 1). Karakteristik pengelolaan yang diamati yaitu persepsi masyarakat terhadap fungsi dan pengelolaan mangrove, dan sikap masyarakat terhadap pengelolaan dan perlindungan mangrove. Pengumpulan data dilakukan melalui observasi dan wawancara dengan masyarakat di tiga kampung. Penentuan responden ditentukan berdasarkan masyarakat yang berhubungan langsung dengan mangrove, yaitu masyarakat pemanfaat sumber daya mangrove. Responden terdiri dari 54 responden dari
Rawa Mekar Jaya, 37 responden dari Sungai Rawa dan 41 responden dari Mengkapan.

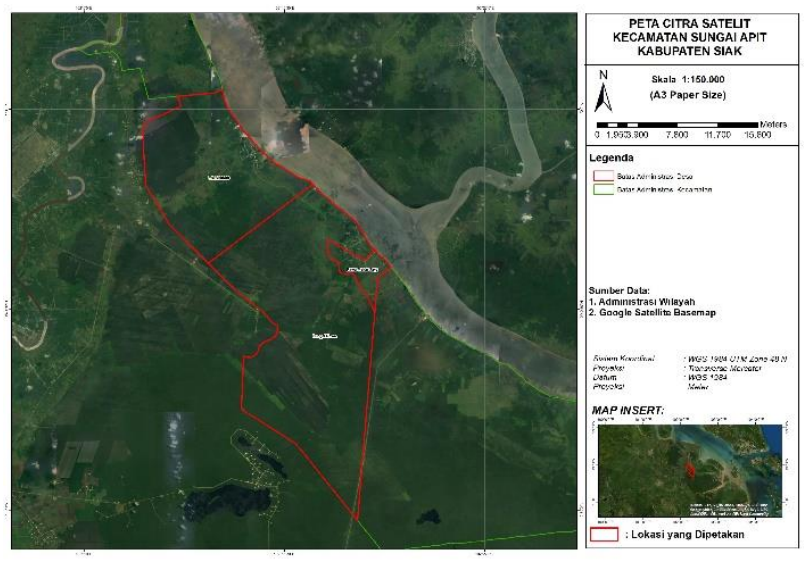

Gambar 1. Peta lokasi penelitian

Pendapat masyarakat diukur berdasarkan jumlah skor dari pertanyaan pada kuesioner dengan menggunakan skala likert. Setiap pertanyaan memiliki skor. Pilihan jawaban meliputi Sangat setuju (SS) dengan skor 4, Setuju (S) dengan skor 3, Netral/abstain (N) dengan skor 3 dan tidak setuju dengan skor 1 (Hakim, 2015; Setiawan, 2017; Sanetiastri et al., 2019; Owuor et al., 2019). Bobot nilai persepsi dirangkum, kemudian dihitung dengan cara mengalikan jumlah responden dengan bobot sehingga menghasilkan skor rata-rata atau nilai dari masing-masing persepsi. Interval kelas ditentukan untuk mendapatkan kisaran skor berdasarkan banyaknya kelas (4), dalam hal ini intervalnya adalah 0,75 . Skor rata-rata atau nilai berupa angka ini kemudian diinterpretasikan berdasarkan kategori nilai. Bila terdapat 4 kisaran nilai maka kategori yang diberikan yaitu sangat buruk, buruk, baik dan sangat baik (Tabel 1) (Hakim, 2015; Setiawan, 2017).

Tabel 1. Skoring persepsi dan perilaku masyarakat setempat berdasarkan Skala Likert

\begin{tabular}{ccc}
\hline No & Kisaran Skor & Keterangan \\
\hline $\mathbf{1}$ & $1,00-1,75$ & Sangat buruk \\
$\mathbf{2}$ & $1,76-2,50$ & Buruk \\
$\mathbf{3}$ & $2,51-3,25$ & Baik \\
$\mathbf{4}$ & $3,26-4,00$ & Sangat baik \\
\hline
\end{tabular}

\section{HASIL DAN PEMBAHASAN}

\section{Persepsi Masyarakat terhadap Fungsi dan Pengelolaan Mangrove}

Nilai persepsi masyarakat terhadap fungsi mangrove di ketiga kampung di Kecamatan Sungai Apit, Siak, Riau (Tabel 2) menunjukkan interpretasi yang sangat baik $(3,60)$. Nilai persepsi masyarakat terhadap fungsi mangrove tertinggi di Kampung Rawa Mekar Jaya $(3,87)$, diikuti Mengkapan $(3,52)$ dan terendah adalah Kampung Sungai Rawa $(3,43)$.

Fungsi ini meliputi fungsi mangrove sebagai tempat rekreasi, mencegah abrasi, melindungi garis 

pantai, menahan intrusi air laut, tempat
keanekaragaman hayati, sebagai nursery ground, menghasilkan kayu, dan sarana pendidikan. Semua fungsi ini sudah dipahami dengan sangat baik oleh responden di Desa Rawa Mekar Jaya, Sungai Rawa, dan Mengkapan. Ini karena responden merupakan masyarakat yang memanfaatkan hutan mangrove secara langsung, sudah adanya sosialisasi dari Pemerintah Daerah setempat, Lembaga Swadaya Masyarakat (LSM), adanya tokoh masyarakat lokal penggerak dan sudah ada beberapa organisasi lokal masyarakat yang terkait mangrove. Perbedaan nilai persepsi masyarakat terhadap pengelolaan mangrove (pengelolaan dan perlindungan mangrove sebagai tanggung jawab bersama) terjadi pada tiga kampung di Kecamatan Sungai Apit, Siak, Riau (Tabel 2). Nilai persepsi masyarakat dari responden Kampung Rawa Mekar Jaya sangat baik (3,59), sedangkan dua kampung lainnya yaitu Sungai Rawa dan Mengkapan dengan interpretasi baik (masing-masing dengan nilai 3,05 dan 3,24 .

Hasil rekapitulasi nilai persepsi masyarakat terhadap fungsi dan pengelolaan mangrove di tiga kampung Kecamatan Sungai Apit, Siak, Riau (Tabel 4) menunjukkan bahwa nilai persepsi masyarakat terhadap fungsi mangrove lebih baik dibandingkan nilai persepsi terhadap pengelolaan mangrove. Kesadaran masyarakat terhadap fungsi mangrove lebih tinggi dibandingkan kesadaran masyarakat untuk mengelola dan melindungi ekosistem mangrove. Persepsi responden dari Desa Rawa Mekar Jaya terhadap fungsi dan pengelolaan mangrove memiliki nilai paling tinggi $(3,73$, sangat baik), diikuti Mengkapan (3,38, sangat baik) dan paling rendah adalah Sungai Rawa (3,24, baik).

\section{Sikap Masyarakat dalam Perlindungan dan Pengelolaan Mangrove}

Nilai sikap masyarakat dalam perlindungan dan pengelolaan mangrove di Kecamatan Sungai Apit, Siak, Riau (Tabel 5 dan 6) secara keseluruhan menunjukkan nilai rerata 2,56 dengan kategori baik. Nilai ini berdasarkan hasil kuesiner dari dua variabel tentang keterlibatan masyarakat dalam pengelolaan dan perlindungan mangrove. Indikator 1 adalah keterlibatan masyarakat dalam pengelolaan dan perlindungan mangrove karena kewajiban sosial dan dalam bentuk gotong royong. Indikator 2 adalah keterlibatan dalam rehabilitasi tidak hanya pada saat proyek atau bukan hanya karena adanya upah.

Sikap masyarakat dalam perlindungan dan pengelolaan mangrove responden asal Rawa Mekar Jaya dan Mengkapan lebih baik dibandingkan responden asal Sungai Rawa (Tabel 5 dan 6). Sikap responden asal Rawa Mekar Jaya dan Mengkapan tentang keterlibatan masyarakat dalam pengelolaan dan perlindungan mangrove karena kewajiban sosial dan dalam bentuk gotong royong (indikator 1) menunjukkan kategori baik, sedangkan sikap responden asal Sungai Rawa tergolong buruk. Sikap masyarakat dari ketiga desa yang berhubungan dengan indikator 2 (keterlibatan dalam rehabilitasi tidak hanya pada saat proyek atau bukan hanya karena adanya upah) tergolong buruk.

Secara keseluruhan nilai sikap masyarakat tergolong baik, namun indikator 2 menunjukkan nilai yang lebih rendah $(2,38$; kategori buruk) dibandingkan variabel 1 (2,74; kategori baik). Sebagian besar masyararakat berpendapat netral apabila partisipasi masyarakat dalam rehabilitasi mangrove bukan karena proyek. Persentase masyarakat yang setuju apabila pelaksanaan rehabilitasi mangrove tanpa adanya upah tergolong rendah, yaitu sekitar $21,6 \%$ untuk Sunga Rawa, 33,3\% untuk Rawa Mekar Jaya dan 39,02\% untuk responden Mengkapan. Ini dapat dimaklumi karena responden umumnya merupakan masyarakat pemanfaat mangrove yang umumnya sumber pendapatan utamanya dari mencari ikan, madu dan sumber daya mangrove lainnya (lokan, bolongan, siput) dan mereka umumnya tidak memiliki lahan pertanian (kebun sawit atau kebun karet) yang membutuhkan waktu dan tenaga. Apabila waktu dan tenaga digunakan untuk alokasi lainnya, misalnya kegiatan rehabilitasi mangrove membutuhkan kompensasi biaya pengganti yang sangat dibutuhkan sebagai sumber penghidupan mereka. Keterlibatan masyarakat dalam upaya rehabilitasi mangrove umumnya ketika ada proyek misalnya dari pemerintah, swasta atau LSM. Namun demikian, sebagian besar masyarakat setuju untuk berperan serta dalam perlindungan dan pengelolaan mangrove. Dalam pelaksanaannya masyarakat lokal di sekitar hutan mangrove bersedia ikut gotong-royong dalam rehabilitasi mangrove.

Hasil ini menunjukkan bahwa persepsi masyarakat terhadap fungsi dan pengelolaan mangrove di kawasan mangrove Kecamatan Sungai Apit yaitu di Kampung Rawa Mekar Jaya, Sungai Rawa dan Mengkapan umumnya sangat baik, namun sikap masyarakat dalam pengelolaan dan perlindungan mangrove tergolong baik. Namun terdapat perbedaan nilai persepsi dan sikap dari masyarat di tiga kampung tersebut, yang mana masyarakat Sungai Rawa menunjukkan persepsi dan sikap yang lebih rendah dibandingkan masyarakat Rawa Mekar Jaya dan Mengkapan. Persepsi masyarakat Sungai Rawa terhadap fungsi dan pengelolaan mangrove tergolong baik, sedangkan untuk masyarakat Rawa Mekar Jaya dan Mengkapan tergolong sangat baik. Sikap masyarakat Sungai Rawa terhadap perlindungan dan pengelolaan mangrove tergolong buruk, sedangkan untuk masyarakat Rawa Mekar Jaya dan Mengkapan tergolong baik. Hutan mangrove di Sungai Rawa lebih luas dibandingkan hutan mangrove di Rawa Mekar Jaya dan Mengkapan, dengan tingkat ketergantungan terhadap mangrove yang lebih tinggi. Namun nilai sikap masyarakat pemanfaat mangrove terhadap perlindungan dan pengelolaan mangrove lebih rendah (dengan kategori buruk). Ini diperkuan dengan adanya kegiatan rehabilitasi mangrove di Sungai Rawa yang 
berlangsung lebih awal (tahun 2008) dari Rawa Mekar Jaya (tahun 2014), namun keberlangsungannya lebih lama di Rawa Mekar Jaya. Kesadaran masyarakat Sungai Rawa untuk berpartisipasi dalam perlindungan dan pengelolaan mangrove lebih rendah dibandingkan dengan masyarakat pemanfaat mangrove Rawa Mekar Jaya dan Mengkapan. Hal ini menjadi ancaman yang akan berpengaruh terhadap upaya perlindungan dan pengelolaan mangrove. Oleh karena itu perlu ditingkatkan kesadaran masyarakat dalam perlindungan dan pengelolaan mangrove.

Masyarakat diberbagai wilayah mangrove lainnya juga menunjukkan kondisi yang demikian, namun sikap dan perilaku dalam pengelolaan mangrove umumnya tergolong buruk. Persepsi masayarakat di sekitar hutan mangrove terhadap kelestarian mangrove di Taman Hutan Raya Ngurah Rai Bali sangat baik, namun perilaku dalam pengelolaan mangrove juga tergolong buruk (Sanetiastri et al., 2019), demikian juga masyarakat lokal di sekitar hutan mangrove di Wonorejo, Surabaya, Jawa Timur (Hakim, 2015). Persepsi atau pemahaman masyarakat tentang pengelolaan mangrove yang baik juga terjadi di kawasan mangrove Desa Seruni Mumbul Kecamatan Pringgabaya Kabupaten Lombok Timur (Basri, 2019). Perilaku masyarakat pesisir dalam melestarikan ekosistem mangrove di Kelurahan Bontang Kuala Kecamatan Bontang Utara, Kota Bontang menunjukkan kriteria baik $(67,21 \%)$, yang didukung didukung oleh persepsi masyarakat tentang konservasi ekosistem mangrove dengan kriteria baik (76,21\%) (Nidyasari et al., 2011). Persepsi masyarakat terhadap pengelolaan mangrove di kawasan mangrove Indramayu menunjukkan nilai positif (Gumilar, 2012). Persepsi masyarakat terhadap keberadaan mangrove di Singkawang, Sambas tergolong tinggi (Khairiansyah et al., 2018). Nilai persepsi masyarakat terhadap fungsi dan pengelolaan mangrove di kawasan Mangrove Muara Gembong Bekasi Jawa Barat tergolong tinggi (Sari et al., 2018). Sebagian besar masyarakat pesisir di kawasan mangrove Teluk Kotania sangat setuju terhadap pengelolaan mangrove, pentingnya keterlibatan masyarakat lokal dan kerjasama antara pemerintah dengan masyarakat lokal (Nanlohy et al., 2014). Persepsi dan sikap masyarakat dalam pelestarian mangrove di Kecamatan Jenu Kabupaten Tuban juga menunjukkan pengaruh yang positif dalam mendukung upaya pelestarian mangrove (Subrihandoyo, 2019).

Hasil studi tentang persepsi masyarakat terhadap fungsi dan pengelolaan mangrove yang sangat baik ini menunjukkan bahwa masyarakat lokal di Sungai Apit sudah memahami tentang fungsi mangrove baik secara langsung maupun tak langsung, yaitu secara ekonomi dan ekologi yang cukup penting untuk keberlangsungan hidup dan kesejahteraan masyarakat. Persepsi ini memungkinkan masyarakat akan terus menjaga dan memanfaatkan ekosistem mangrove secara berkelanjutan. Masyarakat memiliki kesadaran yang tinggi dalam memanfaatkan sumber daya mangrove secara berkelanjutan. Hal ini ditunjukkan dengan sumber daya mangrove yang menjadi sumber penghidupan masyarakat lokal umumnya adalah golongan sumber daya non kayu, antara lain ikan, madu, lokan, siput dan bolongan. Masyarakat lokal yang memanfaatkan kayu mangrove untuk bahan baku arang dan tiang pancang tidak ada, sedangkan masyarakat yang memanfaatkan kayu mangrove untuk kayu bakar sangat sedikit (hanya satu responden).

Sikap masyarakat dalam perlindungan dan pengelolaan mangrove di Sungai Apit, dalam hal ini tentang keterlibatan masyarakat dalam kegiatan rehabilitasi mangrove dengan hasil rerata tergolong baik. Sikap masyarakat terhadap keterlibatan dalam pengelolaan dan perlindungan mangrove karena kewajiban sosial dan dalam bentuk gotong royong tergolong baik, namun sikap masyarakat terhadap keterlibatan dalam rehabilitasi tidak hanya pada saat proyek atau bukan hanya karena adanya upah tergolong buruk. Hanya sedikit masyarakat yang setuju apabila kegiatan rehabilitasi mangrove tanpa adanya upah. Kegiatan rehabilitasi mangrove cukup penting untuk menangggulangi hutan mangrove yang mengalami kerusakan, karena sampai saat ini masih ada ancaman deforestrasi hutan mangrove di Sungai Apit. Kegiatan rehabilitasi meliputi pengadaan bibit dan penanaman bibit mangrove di lahan yang terganggu. Supaya kegiatan rehabilitasi tetap berjalan maka diperlukan antara lain pendanaan sebagai kompensasi terhadap waktu dan tenaga masyarakat yang terpakai. Upaya perlindungan dan pengelolaan mangrove membutuhkan perbaikan dan peningkatan komponen penting dalam pengelolaan mangrove berbasis masyarakat, meliputi kelembagaan lokal yang berhubungan dengan mangrove, pendanaan, kerjasama dengan pihak luar (misalnya LSM), dan strategi rehabilitasi. Kelembagaan lokal di Sungai Apit sudah ada, namun aktivitas dan bentuk kegiatannya perlu ditingkatkan. Alternatif kegiatan yang perlu ditingkatkan misalnya kegiatan Bank Pohon. Bank pohon penting sebagai persediaan bibit untuk rehabilitasi sehingga persediaan bibit mangrove tidak tergantung lagi pada bantuan pihak luar. Adanya Bank pohon juga dapat menambah kegiatan ekowisata mangrove bagi pengunjung berupa penanaman bibit mangrove yang dapat meningkatkan daya tarik ekowisata mangrove, sehingga dapat menambah pendapatan mansyarakat yang terlibat dalam pengadaan bibit. Sumber pendanaan yang berhubungan dengan kegiatan rehabilitasi mangrove juga perlu ditingkatkan misalnya dari dana desa dan kerjasama dengan pihak luar, misalnya LSM. 
Tabel 2. Nilai persepsi masyarakat terhadap fungsi mangrove di Kecamatan Sungai Apit, Siak, Riau

A. Nilai persepsi masyarakat terhadap fungsi mangrove di desa Rawa Mekar Jaya

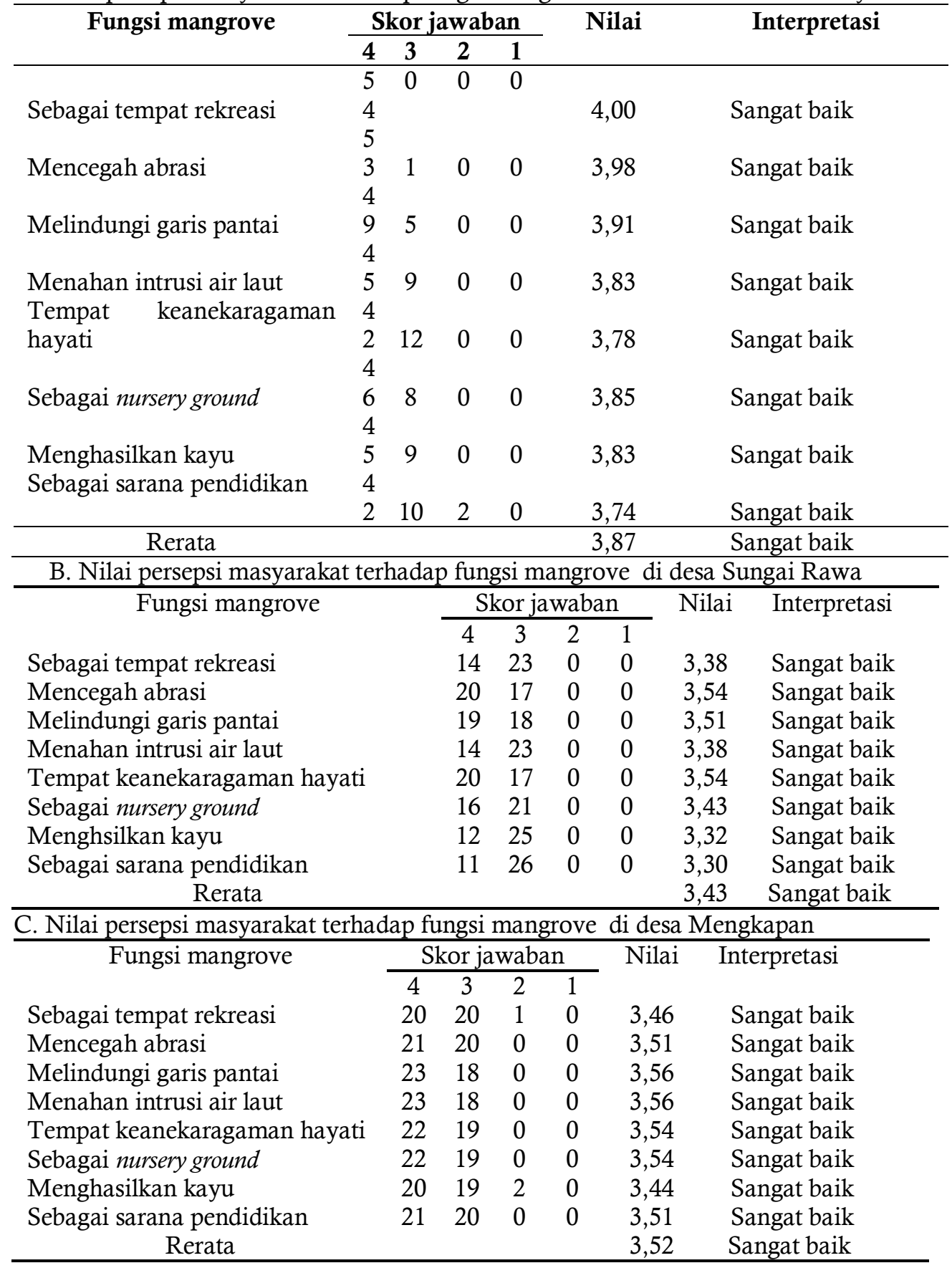

Tabel 3. Nilai persepsi masyarakat terhadap pengelolaan mangrove ${ }^{*}$ di Kecamatan Sungai Apit, Siak, Riau

\begin{tabular}{lrrrrrrr}
\multicolumn{1}{c}{ Desa } & \multicolumn{5}{c}{ Skor jawaban } & Nilai & Interpretasi \\
\cline { 1 - 5 } & 4 & 3 & 2 & 1 & & \\
Rawa Mekar Jaya & 24 & 30 & 0 & 0 & 3,44 & Sangat baik \\
Sungai Rawa & 4 & 31 & 2 & 0 & 3,05 & Baik \\
Mengkapan & 10 & 31 & 0 & 0 & 3,24 & Baik \\
Rerata & & & & & 3,25 & Sangat baik \\
\hline
\end{tabular}


Siti Fatonah, Rasoel Hamidy, Aras Mulyadi, Efriyeldi | DLI 9 (1) (2022) 64-71

Tabel 4. Rekapitulasi nilai persepsi masyarakat terhadap fungsi dan pengelolaan mangrove di Kecamatan Sungai Apit, Siak, Riau

\begin{tabular}{lccccc}
\hline \multicolumn{1}{c}{ Indikator } & \multicolumn{5}{c}{ Nilai } \\
\cline { 2 - 6 } & Rawa Mekar & Sungai & Mengkapa & Rerata & \\
Fungsi & Jaya & Rawa & $\mathrm{n}$ & & \\
Pengelolaan & 3,87 & 3,43 & 3,52 & 3,60 & Sangat Baik \\
Rerata & 3,59 & 3,05 & 3,24 & 3,29 & Sangat Baik \\
Interpretasi & 3,73 & 3,24 & 3,38 & 3,45 & Sangat Baik \\
& Sangat baik & Baik & $\begin{array}{c}\text { Sangat } \\
\text { baik }\end{array}$ & & \\
\hline
\end{tabular}

Tabel 5. Nilai sikap masyarakat dalam pengelolaan dan perlindungan mangrove di Kecamatan Sungai Apit, Siak, Riau

\begin{tabular}{|c|c|c|c|c|c|c|c|}
\hline \multicolumn{8}{|c|}{ A. Rawa Mekar Jaya } \\
\hline & \multirow[t]{2}{*}{ Indikator } & \multicolumn{4}{|c|}{ Skor jawaban } & Nilai & Interpretasi \\
\hline & & 4 & 3 & 2 & 1 & & \\
\hline & 1 & 9 & 29 & 11 & 5 & 2,78 & baik \\
\hline & 2 & 6 & 12 & 36 & 0 & 2,44 & buruk \\
\hline & Rerata & & & & & 2,61 & baik \\
\hline \multicolumn{8}{|c|}{ B. Sungai Rawa } \\
\hline & \multirow[t]{2}{*}{ Indikator } & \multicolumn{4}{|c|}{ Skor jawaban } & Nilai & Interpretasi \\
\hline & & 4 & 3 & 2 & 1 & & \\
\hline & 1 & 8 & 0 & 29 & 0 & 2,43 & buruk \\
\hline & 2 & 2 & 6 & 29 & 0 & 2,27 & buruk \\
\hline & Rerata & & & & & 2,35 & buruk \\
\hline \multicolumn{8}{|c|}{ C. Mengkapan } \\
\hline & \multirow[t]{2}{*}{ Indikator } & \multicolumn{4}{|c|}{ Skor jawaban } & Nilai & Interpretasi \\
\hline & & 4 & 3 & 2 & 1 & & \\
\hline & 1 & 21 & 0 & 20 & 0 & 3,02 & baik \\
\hline & 2 & 2 & 14 & 25 & 0 & 2,44 & buruk \\
\hline & & & & & & 2,73 & baik \\
\hline
\end{tabular}

Keterangan: Indikator 1) Berpartisipasi dalam pengelolaan dan perlindungan mangrove karena kewajiban sosial dan dalam bentuk gotong royong; Indikator 2) Berpartisipasi dalam rehabilitasi tidak hanya pada saat proyek atau karena bukan karena adanya upah

Tabel 6. Rekapitulasi nilai sikap masyarakat dalam pengelolaan dan perlindungan mangrove di Kecamatan Sungai Apit, Siak, Riau

\begin{tabular}{|c|c|c|c|c|}
\hline \multirow[t]{2}{*}{ Indikator } & \multicolumn{4}{|c|}{ Nilai } \\
\hline & Rawa Mekar Jaya & $\begin{array}{l}\text { Sungai } \\
\text { Rawa }\end{array}$ & Mengkapan & Rerata \\
\hline 1 & 2,78 & 2,43 & 3,02 & 2,74 \\
\hline 2 & 2,44 & 2,27 & 2,44 & 2,38 \\
\hline Rerata & 2,61 & 2,35 & 2,73 & 2,56 \\
\hline Interpretasi & Baik & Buruk & Baik & Baik \\
\hline
\end{tabular}




\section{KESIMPULAN}

Persepsi masyarakat terhadap fungsi dan pengelolaan mangrove Sungai Apit tergolong sangat baik, sedangkan sikap masyarakat terhadap perlindungan dan pengelolaan mangrove tergolong baik. Nilai persepsi dan sikap masyarakat Rawa Mekar Jaya dan Mengkapan lebih baik dibandingkan masyarakat Sungai Rawa. Keterlibatan masyarakat dalam kegiatan rehabilitasi umumnya hanya pada saat proyek dan karena adanya upah. Masyarakat memiliki kesadaran yang tinggi dalam memanfaatkan sumber daya mangrove secara berkelanjutan. Masyarakat memiliki kesadaran yang tinggi dalam perlindungan dan pengelolaan mangrove, namun keterlibatannya dalam kegiatan rehabilitasi membutuhkan biaya sebagai kompensasi dari waktu dan tenaga yang terpakai. Oleh karena itu dibutuhkan alternatif kegiatan yang dapat meningkatkan sumber pendanaan dan peningkatan sumber pendanaan dalam kelembagaan lokal yang berhubungan dengan mangrove.

\section{UCAPAN TERIMAKASIH}

Ucapan terima kasih penulis sampaikan kepada masyarakat Desa Rawa Mekar Jaya, Sungai Rawa dan Mengkapan atas bantuan dan kerjasamanya selama penelitian.

\section{DAFTAR PUSTAKA}

Basri, B. (2019). Persepsi Masyarakat Terhadap Pengelolaan Kawasan Mangrove Di Desa Seruni Mumbul Kecamatan Pringgabaya Kabupaten Lombok Timur (Doctoral Dissertation, Fakultas Perikanan).

Badola, R., Barthwal, S., \& Hussain, S. A. (2012). Attitudes of local communities towards conservation of mangrove forests: A case study from the east coast of India. Estuarine, Coastal and Shelf Science, 96, 188-196.

Damastuti, E., \& de Groot, R. (2017). Effectiveness of community-based mangrove management for sustainable resource use and livelihood support: A case study of four villages in Central Java, Indonesia. Journal of Environmental Management, 203: 510-521.

https://doi.org/10.1016/j.jenvman.2017.07.025

Gumilar, I. (2012). Partisipasi Masyarakat Pesisir Dalam Pengelolaan Ekosistem Hutan Mangrove Berkelanjutan Di Kabupaten Indramayu. Jurnal Akuatika Indonesia, 3(2): 244417. http://journal.unpad.ac.id/akuatika/article/view $/ 1623 / 1629$

Hakim, A. M. (2015). Perception, attitude, and participation of the community around about mangrove forest management in Wonorejo, Surabaya, East Java. Bonorowo Wetlands, 5(2):
85-93.

https://doi.org/10.13057/bonorowo/w050204

Juwita, E., Soewardi, K., \& Yonvitner, Y. (2015). Kondisi Habitat Dan Ekosistem Mangrove Kecamatan Simpang Pesak, Belitung Timur Untuk Pengembangan Tambak Udang (Habitat Conditions and Mangrove Ecosystem in Simpang Pesak District, East Belitung for Development of Shrimp Pond). Jurnal Manusia Dan Lingkungan, 22(1): 59. https://doi.org/10.22146/jml.18725

Khairiansyah, M., Zainal, S., \& Nugroho, J. (2018). Persepsi Masyarakat terhadap Keberadaan Hutan Mangrove di Kelurahan Kuala Kecamatan Singkawang. Jurnal Hutan Lestari, 6(2): 416-427. https://jurnal.untan.ac.id/index.php/jmfkh/articl e/view/26098/75676577046

KLHK (Kementerian Lingkungan Hidup dan Kehutanan). 2019. Tutupan Lahan. Kantor Kementerian Lingkungan Hidup dan Kehutanan RI, Jakarta.

Kongkeaw, C., Kittitornkool, J., Vandergeest, P., \& Kittiwatanawong, K. (2019). Explaining success in community based mangrove management: Four coastal communities along the Andaman Sea, Thailand. Ocean and Coastal Management, 178(September 2018), 104822. https://doi.org/10.1016/j.ocecoaman.2019.10482 2

Motoku, A. W., Umar, S., Toknok, B., Kehutanan, J., Kehutanan, F., Tadulako, U., Fakultas, M., Universitas, K., Pengajar, S., Kehutanan, F., \& Tadulako, U. (2014). Nilai Manfaat Hutan Mangrove Di Desa Sausu Peore. Warta Rimba, 2(2): 92-101.

http://jurnal.untad.ac.id/jurnal/index.php/Wart aRimba/article/view/3619/0

Muntalif, B. S., Hasian, O., \& Sembiring, E. (2013). Valuasi Ekonomi Dan Upaya Pengelolaan Hutan Mangrove Di Kecamatan Muara Gembong Kabupaten Bekasi. Jurnal Tehnik Lingkungan, 19(1): 82-90. https://doi.org/10.5614/jt1.2010.16.1.9

Nanlohy, H., Bambang, A. N., Ambaryanto, A., \& Hutabarat, S. (2014). Analisis Persepsi Masyarakat terhadap Pengelolaan Kawasan Mangrove Teluk Kotania. Jurnal Wilayah Dan Lingkungan, 2(1): 89. https://doi.org/10.14710/jwl.2.1.89-98

Nidyasari, Y., Helminuddin \& Purnamasari, E. (2011). Analisis Perilaku Masyarakat Pesisir Dalam Melestarikan Ekosistem Mangrove Di Kelurahan Bontang Kuala Kota Bontang. Jurnal Kehutanan Tropika Humida 4 (1): 80-97. https://jurnalkehutanantropikahumida.zohosites. com/files/Nidyasari $\% 2 \mathrm{C} \% 20 \mathrm{Helminuddin} \% 2 \mathrm{C} \%$ 20Elly.pdf

Owuor, M. A., Icely, J., \& Newton, A. (2019). Community perceptions of the status and threats facing mangroves of Mida Creek, Kenya: Implications for community based management. Ocean and Coastal Management, 175(February): 
$172-179$.

https://doi.org/10.1016/j.ocecoaman.2019.03.02 7

Prawita, N. A. (2018). Analisis Kerusakan Hutan Mangrove Di Wilayah Indonesia. May.

Sanetiastri, C. T., Windia, I. W., \& Astarini, I. A. (2019). Persepsi Dan Perilaku Masyarakat Sekitar Hutan Mangrove Terhadap Pelestarian Mangrove Di Kawasan Taman Hutan Raya Ngurah Rai Bali. Ecotrophic: Jurnal Ilmu Lingkungan (Journal of Environmental Science), 13(2): 135. https://doi.org/10.24843/ejes.2019.v13.i02.p02

Sarhan, M., \& Tawfik, R. (2018). The Economic Valuation of Mangrove Forest Ecosystem Services: Implications for Protected Area Conservation. The George Wright Forum, 35(3), 341.

Sari, Y. P., Salampessy, M. L., \& Lidiawati, I. (2018). Persepsi Masyarakat Pesisir dalam Pengelolaan Ekosistem Hutan Mangrove di Muara Gembong Bekasi Jawa Barat. Perennial, 14(2): 78-85. https://doi.org/10.24259/perennial.v14i2.5303

Setiawan, H. (2017). Persepsi Dan Sikap Masyarakat Terhadap Konservasi Ekosistem Mangrove Di Pulau Tanakeke Sulawesi Selatan. Jurnal Penelitian Sosial Dan Ekonomi Kehutanan, 14(1): 57-70.

https://doi.org/10.20886/jsek.2017.14.1.57-70.
Sondak, C. F. A., Kaligis, E. Y., \& Bara, R. A. (2019). Economic valuation of Lansa Mangrove forest, north Sulawesi, Indonesia. Biodiversitas, 20(4): 978-986. https://doi.org/10.13057/biodiv/d200407

Subrihandoyo, S. (2019). Persepsi Dan Perilaku Masyarakat Dalam Pelestarian Hutan Mangrove Di Kecamatan Jenu Kabupaten Tuban (Doctoral Dissertation, Upn" Veteran" Jatim).

Widiastuti, M. M., Ruata, N. N., \& Arifin, T. (2016). Valuasi Ekonomi Ekosistem Mangrove Di Wilayah Pesisir Kabupaten Merauke. Jurnal Sosial Ekonomi Kelautan Dan Perikanan, 11(2): 147. https://doi.org/10.15578/jsekp.v11i2.3856

Winarno, S., Effendi, H., \& Damar, A. (2016). Tingkat Kerusakan Dan Estimasi Nilai Klaim Kerusakan Ekosistem Mangrove Di Teluk Bintan, Kabupaten Bintan. Jurnal Ilmu Dan Teknologi Kelautan Tropis, 8(1): 115-128. PL), IPB. https://doi.org/10.29244/jitkt.v8i1.12500. 